\title{
Zinc as a Second Messenger of Mitogenic Induction
}

\author{
Effects on Diadenosine Tetraphosphate $\left(A p_{4} A\right)$ and DNA Synthesis
}

\author{
FRIEDRICH GRUMMT, CHRISTA WEINMANN-DORSCH, \\ JÜRGEN SCHNEIDER-SCHAULIES and \\ ANGELIKA LUX
}

Institut für Biochemie der Universität Würzburg, D-8700 Würzburg, FRG

\begin{abstract}
DNA synthesis and adenosine $\left(5^{\prime}\right)$ tetraphosphate $\left(5^{\prime}\right)$ adenosine $\left(\mathrm{Ap}_{4} \mathrm{~A}\right)$ levels decrease in cells treated with EDTA. The inhibitory effect of EDTA can be reversed with micromolar amounts of $\mathrm{ZnCl}_{2}$. $\mathrm{ZnCl}_{2}$ in micromolar concentrations also inhibits $\mathrm{Ap}_{4} \mathrm{~A}$ hydrolase and stimulates amino acid-dependent $\mathrm{Ap}_{4} \mathrm{~A}$ synthesis, suggesting that $\mathrm{Zn}^{2+}$ is modulating intracellular $\mathrm{Ap}_{4} \mathrm{~A}$ pools. Serum addition to G1-arrested cells enhances uptake of $\mathrm{Zn}$, whereas serum depletion leads to a fivefold decrease of the rates of zinc uptake. These results are discussed by regarding $\mathrm{Zn}^{2+}$ as a putative 'second messenger' of mitogenic induction and $\mathrm{Ap}_{4} \mathrm{~A}$ as a possible 'third messenger' and trigger of DNA synthesis. (c) 1986 Academic Press, Inc.
\end{abstract}

Mitogenic stimulation of quiescent mammalian cells is characterized by progression through the G1 period and initiation of DNA synthesis at the G1/S phase boundary. The primary mitogenic signal triggering these events is the interaction between extracellular growth factors (PDGF, EGF, FGF etc.) with their cognate membrane receptors. Receptor binding is followed by patching and internalization of clustered mitogen-receptor complexes. After endocytosis the complexes are transported by clathrin-coated vesicles to lysosomes and degraded. No recycling of receptors or growth factors is known. The link between these events and stimulation of DNA synthesis, which usually occurs 8-12 h after exposure of cells to growth factors, is unknown. But it is generally accepted that the initiation of DNA replication in the nucleus after entry into $S$ phase is under the control of cytoplasmic components $[1,2]$. The cytoplasmic factor seems to act as a positive regulatory signal, i.e., as an inducer of replication [3].

Previous studies [4] indicated that the component inducing DNA synthesis is produced after mitogenic stimulation by the cell itself and that it is accumulated gradually during progression through the G1 phase until a critical threshold concentration is reached which determines entry into $\mathrm{S}$ phase. A favorite candidate for such a signal molecule is adenosine $\left(5^{\prime}\right)$ tetraphospho( $\left.5^{\prime}\right)$ adenosine $\left(\mathrm{Ap}_{4} \mathrm{~A}\right)$. This purine nucleotide has been suggested, on the basis of its high metabolic lability and the correlation of its pool sizes with the growth- and cell cycle state of eukaryotic cells, to be part of the intracellular signal chain of mitogenic induction [5-8]. This hypothesis was strongly supported by the obser- 
vation that the site of its intracellular activity is the DNA replicative machinery. Addition of $\mathrm{Ap}_{4} \mathrm{~A}$ to permeabilized G1-arrested baby hamster kidney (BHK) cells yielded initiation of DNA replication in the quiescent cells $[9,10] . \mathrm{Ap}_{4} \mathrm{~A}$ has been demonstrated to bind as a specific ligand to calf thymus DNA polymerase $\alpha$ (deoxynucleosidetriphosphate: DNA deoxynucleotidyl transferase) holoenzyme $\left(M_{r} 404000\right)$ and to affinity label a subunit of $M_{r} 57000$ [11]. Also the high molecular weight (HMW) (660000) and low molecular weight (LMW) (145000) forms of DNA polymerase $\alpha$ of human HeLa cells were shown to possess highly specific, non-covalent, $\mathrm{Ap}_{4} \mathrm{~A}$-binding activity [12]. The dissociation constants were determined to be $0.27 \mu \mathrm{M}$ for the calf thymus enzyme and $16-22 \mu \mathrm{M}$ for the HeLa DNA polymerase $\alpha$.

There is accumulating evidence that $\mathrm{Ap}_{4} \mathrm{~A}$ could be involved in the priming reaction of mammalian DNA polymerase $\alpha$ holoenzyme. $\mathrm{Ap}_{4} \mathrm{~A}$ was shown by Rapaport et al. [13] to act as a primer for DNA synthesis in vitro by DNA polymerase $\alpha$ from HeLa cells with poly(dT) and by Zamecnik et al. [14] with a double-stranded (ds) synthetic polymer as a template. Our recent results demonstrate that $\mathrm{Ap}_{4} \mathrm{~A}$ primes DNA replication by calf thymus DNA polymerase $\alpha$ in vitro with circular single-stranded (ss) M13 phage DNA as a template at concentrations of about $0.1 \mu \mathrm{M}$ [15].

To further substantiate the hypothesis of $\mathrm{Ap}_{4} \mathrm{~A}$ being a putative positive signal molecule triggering onset of DNA synthesis, we studied factors influencing both intracellular $\mathrm{Ap}_{4} \mathrm{~A}$ levels and the replicative machinery. Here we describe experiments suggesting that $\mathrm{Zn}^{2+}$ plays an important role in the transmission of the primary, extracellular mitogenic signal, i.e., growth factor-receptor binding, into intracellular events, expansion of $\mathrm{Ap}_{4} \mathrm{~A}$ pools and onset of DNA synthesis.

\section{MATERIALS AND METHODS}

$\left[{ }^{3} \mathrm{H}\right] \mathrm{Ap}_{4} \mathrm{~A}(20 \mathrm{Ci} / \mathrm{mmole})$ was synthesized as described [9]. ATP, $\mathrm{Ap}_{4} \mathrm{~A}$, alkaline phosphatase and snake venom phosphodiesterase were from Boehringer, Mannheim; ${ }^{65} \mathrm{Zn}$ and $\left[{ }^{3} \mathrm{H}\right]$ thymidine (30 $\mathrm{Ci} / \mathrm{mmole}$ ) were from Amersham.

\section{Cell Culture and in vivo Measurement of DNA Synthesis and Zn Uptake}

Baby hamster kidney (BHK) cells were cultured in Dulbecco's modified Eagle medium (DMEM) containing $10 \%$ newborn calf serum, penicillin $(100 \mathrm{U} / \mathrm{ml})$, and streptomycin $(100 \mu \mathrm{g} / \mathrm{ml})$ in $15-\mathrm{cm}$ dishes as described [16]. G1-arrested cells were obtained by culturing cells with $0.3 \%$ serum for $48 \mathrm{~h}$. For measuring DNA synthesis and $\mathrm{Zn}$ uptake $5 \times 10^{4}$ BHK cells were plated in $31 / 2-\mathrm{cm}$ dishes with 2 $\mathrm{ml}$ medium. DNA synthesis was measured by adding $\left[{ }^{3} \mathrm{H}\right]$ thymidine (final concentration, $1 \mu \mathrm{M}$ ) for 1 h. The medium was removed, the cultures washed, and trichloroacetic acid (TCA)-precipitable radioactivity determined. $\mathrm{Zn}$ uptake was determined by adding $0.1 \mu \mathrm{Ci}^{65} \mathrm{Zn}$ to each of two triplicate sets of $31 / 2-\mathrm{cm}$ dishes. One triplicate set was incubated for $30 \mathrm{~min}$ at $37^{\circ} \mathrm{C}$, the second set was precooled for $15 \mathrm{~min}$ at $0^{\circ} \mathrm{C}$ and incubated after ${ }^{65} \mathrm{Zn}$ addition for $30 \mathrm{~min}$ on ice. After incubation cells were quickly washed three times with $2 \mathrm{ml}$ ice-cold saline, scraped off the dishes with $1 \mathrm{ml} 0.5 \%$ Triton X-100 and the radioactivity was determined in a toluene/Triton-based scintillation cocktail. Uptake values were calculated by background $\left(0^{\circ} \mathrm{C}\right.$ values) subtraction. 


\section{$\mathrm{Ap}_{4} \mathrm{~A}$ Assay}

For $\mathrm{Ap}_{4} \mathrm{~A}$ determination $10^{8}$ cells were used per assay. After medium removal cultures were washed twice with cold saline, then $2 \mathrm{ml} 5 \%$ formic acid were added to the cultures and the cells scraped off. The suspensions were centrifuged $(10 \mathrm{~min}, 10000 \mathrm{~g})$, the pellets were washed once with 2 $\mathrm{ml}$ formic acid, the supernatants were combined, $0.1 \mu \mathrm{Ci}\left[{ }^{3} \mathrm{H}\right] \mathrm{Ap}_{4} \mathrm{~A}$ was added as internal standard, and the nucleotide extracts were lyophilized. The nucleotide extracts were dissolved in $2 \mathrm{ml} 20 \mathrm{mM}$ Tris-formate, $\mathrm{pH} 8.0,1 \mathrm{mM} \mathrm{MgCl}$, and digested with 1 unit of alkaline phosphatase (purified on Sephadex G-75) at $37^{\circ} \mathrm{C}$ until no significant ATP moiety was observed with the luciferin/luciferase system. The digest was diluted with $20 \mathrm{ml} 0.12 \mathrm{M}$ ammonium bicarbonate buffer, $\mathrm{pH} 8.2$, applied on a $(15 \times 0.7 \mathrm{~cm})$ Whatman DE52 column after equilibration with the same buffer. The column was washed with $50 \mathrm{ml}$ of the equilibration buffer and $\mathrm{Ap}_{4} \mathrm{~A}$ was eluted with $30 \mathrm{ml} 0.3 \mathrm{M}$ ammonium bicarbonate. After lyophilization, $\mathrm{Ap}_{4} \mathrm{~A}$ was solved in $100 \mu \mathrm{l} \mathrm{H} \mathrm{H}_{2} \mathrm{O}$ and $700 \mu \mathrm{l}$ sample buffer $(0.1 \mathrm{M}$ Tris-acetate, $\mathrm{pH}$ 7.75, $2 \mathrm{mM}$ EDTA) and $200 \mu \mathrm{l}$ luciferin/luciferase (Lumit PM, Lumac A.G.) were added. After determination of the ATP background, $5 \mu$ l snake venom phosphodiesterase $(0.15$ units) were added and the $\mathrm{Ap}_{4} \mathrm{~A}$ content measured as expressed by ATP generation after phosphodiesterase digestion. The amount of $A_{4} A$ generated was calculated from an ATP and $A_{4} A$ standard curve. The method is suitable to determine unlabelled $\mathrm{Ap}_{4} \mathrm{~A}$ content even in cells from quiescent cultures with $\mathrm{Ap}_{4} \mathrm{~A}$ levels as low as $0.01 \mu \mathrm{M}$. Ap ${ }_{4} \mathrm{~A}$ values are given in molar concentrations. Cell volumes were routinely measured by flow cytophotometry.

The assay applied here is not absolutely specific for $\mathrm{Ap}_{4} \mathrm{~A}$ since other adenosine( $\left.5^{\prime}\right)$ tetraphospho $\left(5^{\prime}\right)$ nucleosides $\left(\mathrm{Ap}_{4} \mathrm{~N}\right)$ can be measured with $50 \%$ yield in comparison to $\mathrm{Ap}_{4} \mathrm{~A}$ as well. However, the $\mathrm{Ap}_{4} \mathrm{~A}$ levels determined in randomly growing cultures by the method applied here are similar to those determined previously by a more specific method [5].

\section{$\mathrm{Ap}_{4} \mathrm{~A}$ Hydrolase Assay}

$10^{7}$ BHK cells were washed twice with saline, scraped off the dishes and suspended in buffer E (20 $\mathrm{mM}$ Tris- $\mathrm{HCl}, \mathrm{pH} 7.5,1 \mathrm{mM} \mathrm{MgCl}, 0.1 \mathrm{mM}$ EDTA, $7 \mathrm{mM}$ 2-mercaptoethanol, $1 \%$ Nonidet P40, $0.7 \%$ sodium deoxycholate). After swelling for $10 \mathrm{~min}$ at $0^{\circ} \mathrm{C}$ the cells were homogenized and centrifuged ( $15 \mathrm{~min}, 10000 \mathrm{rpm}$ ) and the supernatant dialysed for $16 \mathrm{~h}$. Fifty $\mu \mathrm{l}$ samples containing 10 $\mu \mathrm{l}$ extract or purified $\mathrm{Ap}_{4} \mathrm{~A}$ hydrolase, $12 \mu \mathrm{l} 10 \mu \mathrm{M}$ Ap ${ }_{4} \mathrm{~A}$ solution, $1 \mu \mathrm{l}\left[{ }^{3} \mathrm{H}\right] \mathrm{Ap}_{4} \mathrm{~A}(20 \mathrm{Ci} / \mathrm{mmole}), 17 \mu \mathrm{l}$ buffer $\mathrm{E}$ and $10 \mu \mathrm{l} \mathrm{ZnCl}$ at various concentrations were incubated for $5 \mathrm{~min}$ at $37^{\circ} \mathrm{C}$. The reaction was stopped by adding $5 \mu \mathrm{l}$ of concentrated formic acid and the reaction products were analysed by chromatography on polyethyleneimine thin-layer plates. For quantification, thin-layer plates were cut into pieces and the radioactivity determined.

\section{$\mathrm{Ap}_{4}$ A-Synthetase Activity Assay}

Cell extracts were prepared as described for $\mathrm{Ap}_{4} \mathrm{~A}$ hydrolase assays. To determine $\mathrm{Ap}_{4} \mathrm{~A}$ synthetase activity $100 \mu \mathrm{l}$ samples containing $50 \mu \mathrm{l}$ extract, $20 \mathrm{mM}$ Tris- $\mathrm{HCl}, \mathrm{pH} 7.8,12.5 \mathrm{mM} \mathrm{MgCl}, 1 \mathrm{mM}$ ATP, $\mathrm{ZnCl}_{2}$ at various concentrations were incubated for $1 \mathrm{~h}$ at $37^{\circ} \mathrm{C}$ in the presence or absence of a mixture of all $20 \mathrm{~L}$-amino acids at $1 \mathrm{mM}$ final concentration. The reaction was stopped by addition of 5 $\mu \mathrm{l}$ concentrated formic acid and the $\mathrm{Ap}_{4} \mathrm{~A}$ synthesized in the reaction mixture determined as described above.

\section{RESULTS}

\section{Effects of EDTA and $\mathrm{Zn}^{2+}$ on DNA Synthesis in BHK Cells}

Addition of EDTA to the tissue culture medium at concentrations significantly lower than those of the $\mathrm{Mg}^{2+}$ and $\mathrm{Ca}^{2+}$ ions in the medium (together approx. 2.6 $\mathrm{mM}$ ) resulted in more than $95 \%$ inhibition of DNA synthesis (fig. 1). $95 \%$ inhibition of $\left[{ }^{3} \mathrm{H}\right]$ thymidine incorporation was observed $13 \mathrm{~h}$ after application of $1 \mathrm{mM}$ EDTA (fig. 2). The inhibitory effect of EDTA on DNA synthesis could be fully reversed by addition of $\mathrm{Zn}^{2+}$ to the culture medium in a dose-dependent 

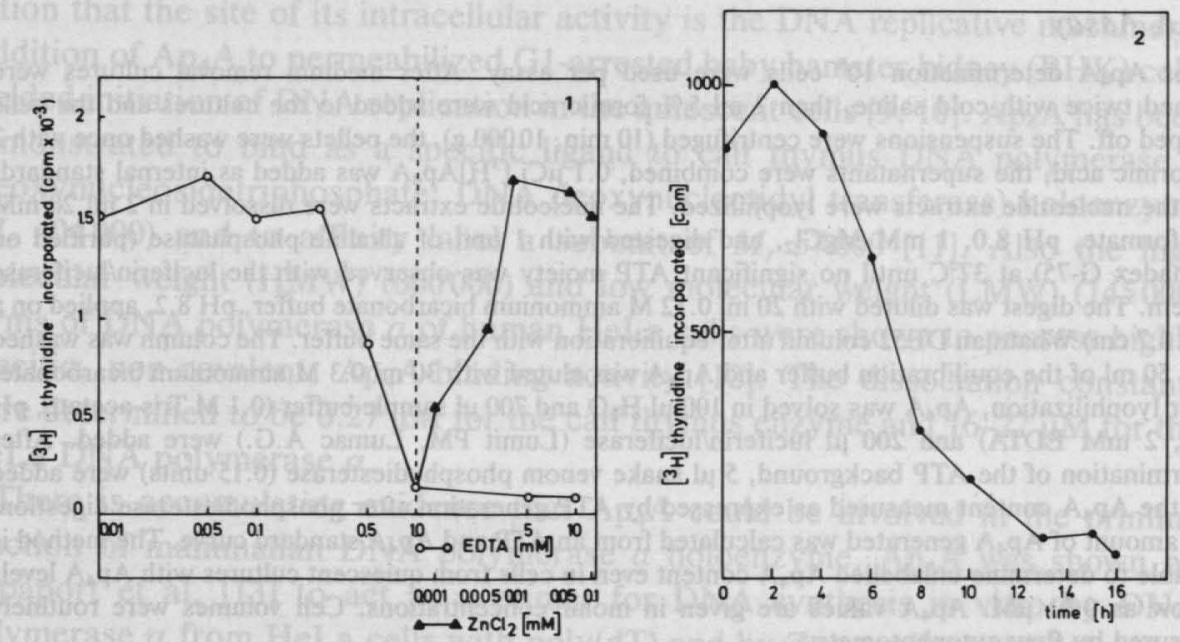

Fig. 1. Inhibition of DNA synthesis in BHK fibroblasts by increasing concentrations of EDTA (O). EDTA was added to growing cultures for $16 \mathrm{~h}$ and $\left[{ }^{3} \mathrm{H}\right]$ thymidine incorporation into TCA-precipitable material determined by pulse-labelling for $30 \mathrm{~min}$ with $\left[{ }^{3} \mathrm{H}\right]$ thymidine, $(\boldsymbol{\Delta})$ reversal of the inhibitory effect of EDTA on DNA synthesis by addition of increasing amounts of $\mathrm{ZnCl}_{2}$ in the presence of 1 $\mathrm{mM}$ EDTA. Exponentially growing BHK cells were preincubated for $16 \mathrm{~h}$ with $1 \mathrm{mM}$ EDTA, then various amounts of $\mathrm{ZnCl}_{2}$ were added for $8 \mathrm{~h}$.

Fig. 2. Time course of inhibition of DNA synthesis in BHK fibroblasts by EDTA. One mM EDTA was added to exponentially growing cultures and DNA synthesis measured by pulse-labelling for 30 min with $\left[{ }^{3} \mathrm{H}\right]$ thymidine as described in the caption to fig. 1 .

manner. These observations are consistent with previously reported data concerning the effects of chelating agents and $\mathrm{Zn}^{2+}$ on DNA synthesis in animal cells [17]. Fig. 1 demonstrates that addition of $10 \mu \mathrm{M} \mathrm{Zn}{ }^{2+}$ fully restores DNA synthesis within $8 \mathrm{~h}$ in BHK cells pretreated with $1 \mathrm{mM}$ EDTA for $16 \mathrm{~h}$. Fig. 3 shows that this effect is specific for $\mathrm{Zn}^{2+}$ ions, $\mathrm{Fe}^{3+}, \mathrm{Mg}^{2+}$ or $\mathrm{Ca}^{2+}$ ions cannot prevent or reverse the inhibitory effect of EDTA.

\section{Effect of EDTA and $\mathrm{Zn}^{2+}$ on $\mathrm{Ap}_{4} \mathrm{~A}$ Levels in BHK Cells}

Since $\mathrm{Ap}_{4} \mathrm{~A}$ levels fluctuate correlated with the growth and cell cycle state of BHK cells [6] we addressed the question whether the effects of EDTA and $\mathrm{Zn}^{2+}$ on the DNA-synthesizing activity could be mediated by $\mathrm{Ap}_{4} \mathrm{~A}$. Therefore, we studied the effects of $\mathrm{Zn}^{2+}$ withdrawal by EDTA and its reversal by exogenous $\mathrm{Zn}^{2+}$ on intracellular $\mathrm{Ap}_{4} \mathrm{~A}$ levels. $\mathrm{Zn}^{2+}$ depletion by addition of $1 \mathrm{mM}$ EDTA to the culture medium leads to a decrease of the intracellular $\mathrm{Ap}_{4} \mathrm{~A}$ concentration of exponentially growing BHK cells from 1.7 to $0.14 \mu \mathrm{M}$ (fig. 4). Addition of $\mathrm{ZnCl}_{2}$ to these cells results in an increase to $1.4 \mu \mathrm{M} \mathrm{Ap}{ }_{4} \mathrm{~A}$ at $10 \mu \mathrm{M} \mathrm{ZnCl}_{2}$, and $1.9 \mu \mathrm{M} \mathrm{Ap}{ }_{4} \mathrm{~A}$ at $50 \mu \mathrm{M} \mathrm{ZnCl} 2$. Inhibition of DNA synthesis parallels the decrease of $\mathrm{Ap}_{4} \mathrm{~A}$ levels, and the time of onset of DNA synthesis upon application of $\mathrm{Zn}^{2+}$ is correlated with the concentration of cellular $\mathrm{Ap}_{4} \mathrm{~A}$. These results suggest that 


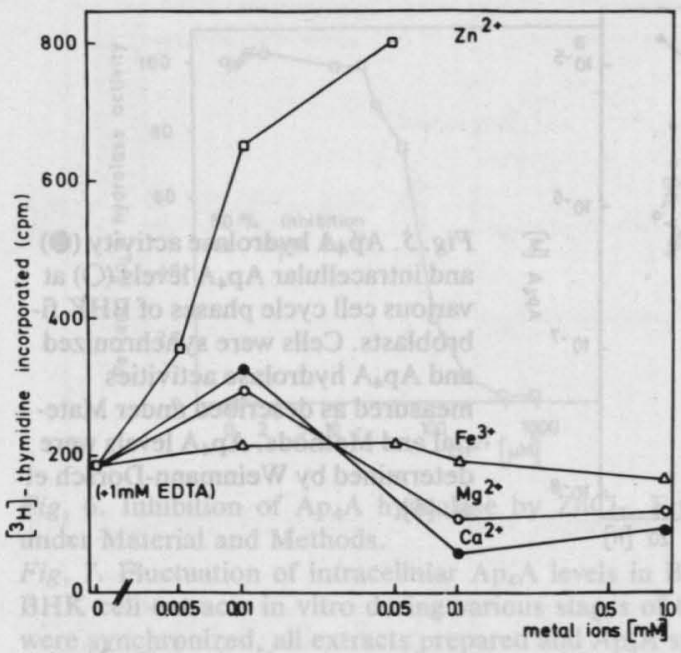

Fig. 3. Effects of metal ions on DNA synthesis of BHK fibroblasts inhibited by 1 mM EDTA. Treatment as described in the caption to fig. 1 .

$\mathrm{Ap}_{4} \mathrm{~A}$ is involved in the regulation of DNA synthesis and that its concentration in living cells is controlled by $\mathrm{Zn}^{2+}$.

\section{$A p_{4} A$ Hydrolase Activity Changes Inversely to the $A p_{4} A$ Concentration during Cell Cycle}

The dramatic fluctuations of $\mathrm{Ap}_{4} \mathrm{~A}$ pools in correlation with growth rate and cell cycle state led to the question how those changes are brought about in

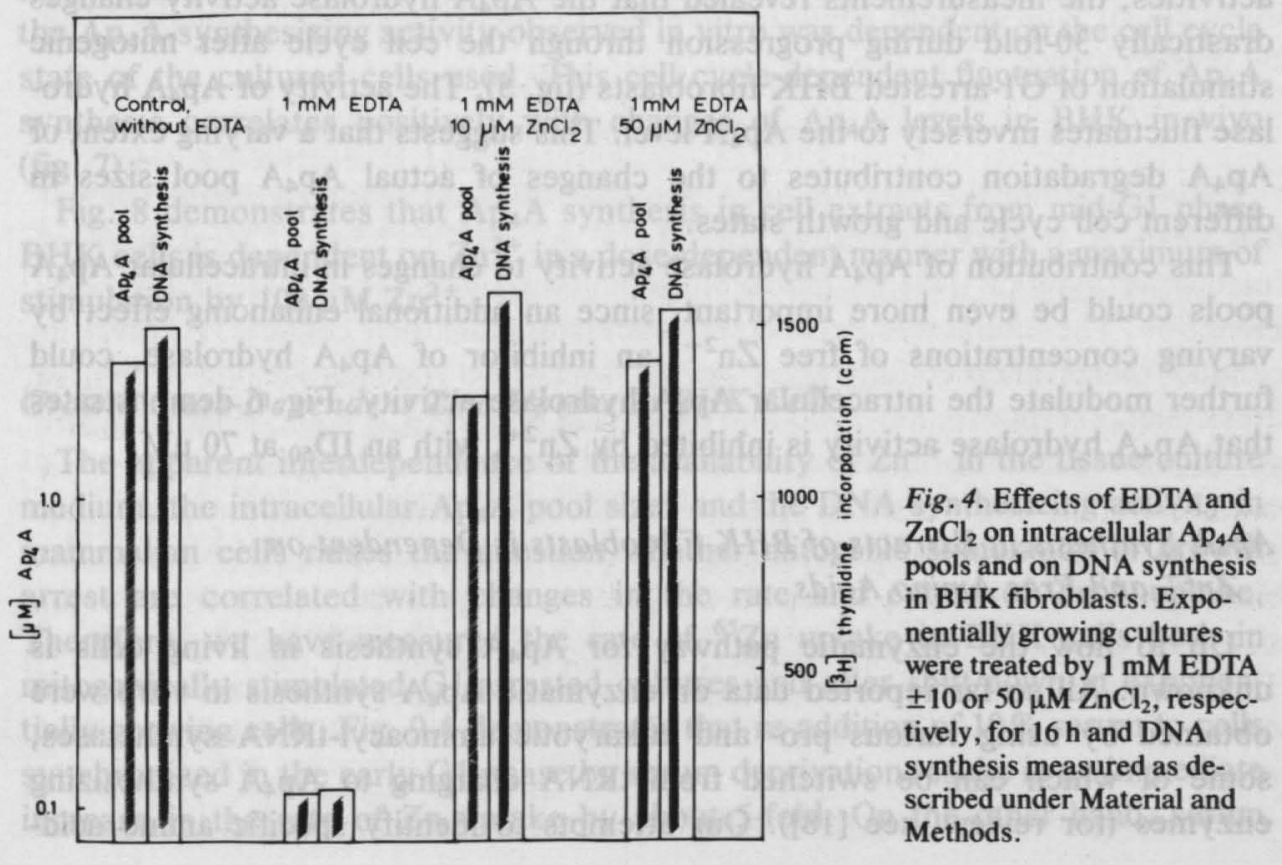




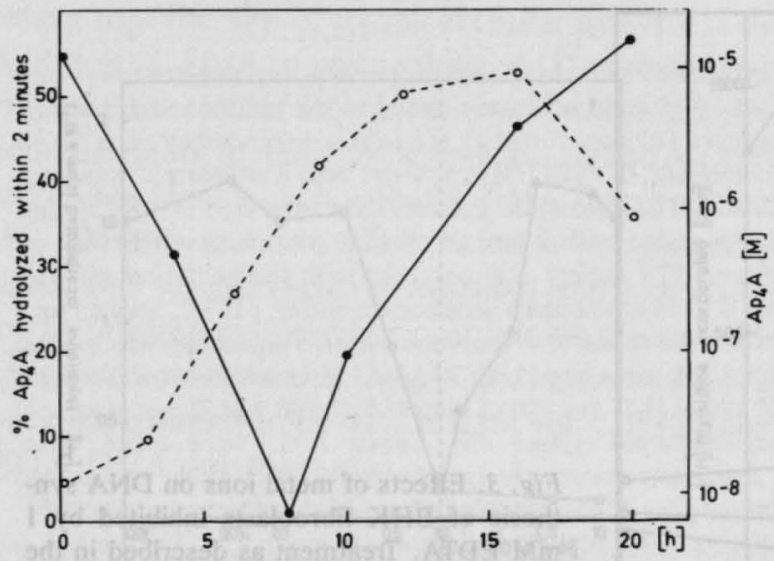

Fig. 5. $\mathrm{Ap}_{4} \mathrm{~A}$ hydrolase activity $(\mathrm{O})$ and intracellular $\mathrm{Ap}_{4} \mathrm{~A}$ levels $(\mathrm{O})$ at various cell cycle phases of BHK fibroblasts. Cells were synchronized and $\mathbf{A p}_{4} \mathrm{~A}$ hydrolase activities measured as described under Material and Methods. Ap 4 A levels were determined by Weinmann-Dorsch et al. [6].

response to growth and cell cycle-controlling signals and whether $\mathrm{Zn}^{2+}$ is involved as a mediator. Intracellular $\mathrm{Ap}_{4} \mathrm{~A}$ concentrations could be controlled by influencing the biosynthesis or the degradation of $\mathrm{Ap}_{4} \mathrm{~A}$. Therefore we studied whether changes of the activity of the specific enzyme for $\mathrm{Ap}_{4} \mathrm{~A}$ catabolism, i.e., of $\mathrm{Ap}_{4} \mathrm{~A}$ hydrolase, correlate with fluctuations of intracellular $\mathrm{Ap}_{4} \mathrm{~A}$ pools at different growth and cell cycle states. In the course of these experiments we made use of the fact that the specific $\mathrm{Ap}_{4} \mathrm{~A}$ hydrolase activity in cell extracts can be inhibited by $100 \mu \mathrm{M} \mathrm{ZnCl}_{2}$ (see below), whereas unspecific phosphodiesterase activities cannot. On subtracting the basal level of unspecific phosphodiesterase activities, the measurements revealed that the $\mathrm{Ap}_{4} \mathrm{~A}$ hydrolase activity changes drastically 30-fold during progression through the cell cycle after mitogenic stimulation of G1-arrested BHK fibroblasts (fig. 5). The activity of $\mathrm{Ap}_{4} \mathrm{~A}$ hydrolase fluctuates inversely to the $\mathrm{Ap}_{4} \mathrm{~A}$ level. This suggests that a varying extent of $\mathrm{Ap}_{4} \mathrm{~A}$ degradation contributes to the changes of actual $\mathrm{Ap}_{4} \mathrm{~A}$ pool sizes in different cell cycle and growth states.

This contribution of $\mathrm{Ap}_{4} \mathrm{~A}$ hydrolase activity to changes in intracellular $\mathrm{Ap}_{4} \mathrm{~A}$ pools could be even more important, since an additional enhancing effect by varying concentrations of free $\mathrm{Zn}^{2+}$, an inhibitor of $\mathrm{Ap}_{4} \mathrm{~A}$ hydrolase, could further modulate the intracellular $\mathrm{Ap}_{4} \mathrm{~A}$ hydrolase activity. Fig. 6 demonstrates that $\mathrm{Ap}_{4} \mathrm{~A}$ hydrolase activity is inhibited by $\mathrm{Zn}^{2+}$, with an $\mathrm{ID}_{50}$ at $70 \mu \mathrm{M}$.

\section{$A p_{4} A$ Synthesis in Extracts of BHK Fibroblasts is Dependent on $\mathrm{Zn}^{2+}$ and Free Amino Acids}

Up to now the enzymatic pathway for $A_{4} A$ synthesis in living cells is unknown. All so far reported data on enzymatic $A_{4} A$ synthesis in vitro were obtained by using various pro- and eukaryotic aminoacyl-tRNA synthetases, some of which can be switched from tRNA charging to $\mathrm{Ap}_{4} \mathrm{~A}$ synthesizing enzymes (for review, see [18]). Our attempts to identify specific amino acid- 

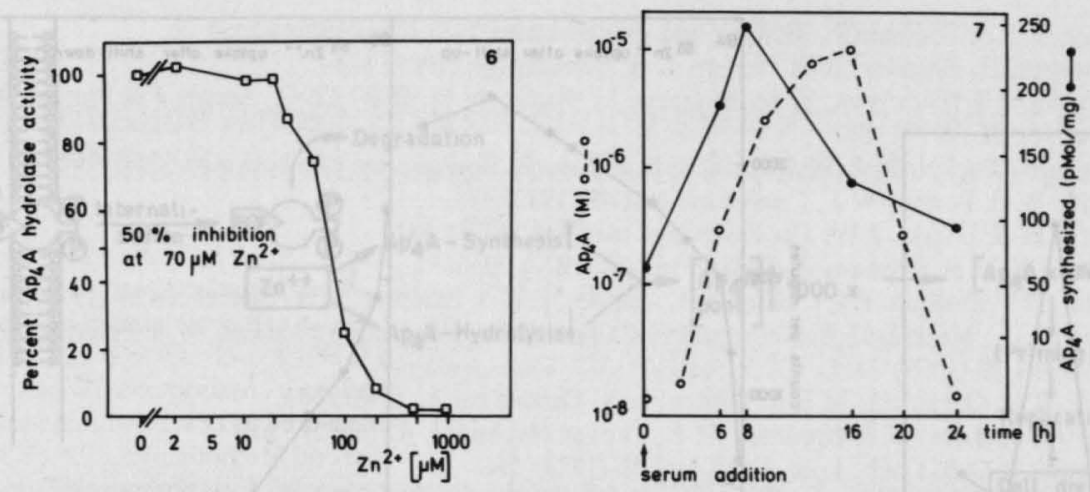

Fig. 6. Inhibition of $\mathrm{Ap}_{4} \mathrm{~A}$ hydrolase by $\mathrm{ZnCl}_{2}$. Enzyme activities were determined as described under Material and Methods.

Fig. 7. Fluctuation of intracellular $\mathrm{Ap}_{4} \mathrm{~A}$ levels in $\mathrm{BHK}$ cells and of $\mathrm{Ap}_{4} \mathrm{~A}$ synthesizing activity in BHK cell extracts in vitro during various stages of the cell division cycle. BHK fibroblast cultures were synchronized, all extracts prepared and $\mathrm{Ap}_{4} \mathrm{~A}$ synthesis activity determined as described under Material and Methods.

independent $\mathrm{Ap}_{4} \mathrm{~A}$ synthetases in mammalian cell extracts led to negative results. Incubation of extensively dialysed cell extracts from BHK cells of various cell cycle phases, together with $1 \mathrm{mM}$ ATP and $12.5 \mathrm{mM} \mathrm{MgCl}_{2}$ at $\mathrm{pH} 7.8$ and $37^{\circ} \mathrm{C}$, yielded significant amounts of newly synthesized $\mathrm{Ap}_{4} \mathrm{~A}$, but only when both an amino acid mixture and $\mathrm{ZnCl}_{2}$ was added (data not shown).

In the presence of $50 \mu \mathrm{M} \mathrm{Zn}{ }^{2+}$ and of a $1 \mathrm{mM}$ amino acid mixture a significant $\mathrm{Ap}_{4} \mathrm{~A}$ synthesis was observed in subcellular BHK extracts in vitro. The extent of the $\mathrm{Ap}_{4} \mathrm{~A}$-synthesizing activity observed in vitro was dependent on the cell cycle state of the cultured cells used. This cell cycle-dependent fluctuation of $\mathrm{Ap}_{4} \mathrm{~A}$ synthesis correlates positively with changes of $\mathrm{Ap}_{4} \mathrm{~A}$ levels in $\mathrm{BHK}$ in vivo (fig. 7).

Fig. 8 demonstrates that $\mathrm{Ap}_{4} \mathrm{~A}$ synthesis in cell extracts from mid-G1 phase BHK cells is dependent on $\mathrm{Zn}^{2+}$ in a dose-dependent manner with a maximum of

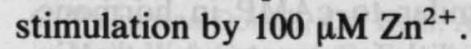

\section{Growth State-Dependent Zinc Uptake in BHK Cells}

The apparent interdependence of the availability of $\mathrm{Zn}^{2+}$ in the tissue culture medium, the intracellular $\mathrm{Ap}_{4} \mathrm{~A}$ pool sizes and the DNA synthesizing activity in mammalian cells raises the question whether mitogenic stimulation or growth arrest are correlated with changes in the rate and extent of $\mathrm{Zn}^{2+}$ uptake. Therefore, we have measured the rate of ${ }^{65} \mathrm{Zn}$ uptake in BHK cells both in mitogenically stimulated G1-arrested cultures and after shift-down in exponentially growing cells. Fig. $9 A$ demonstrates that re-addition of $10 \%$ serum to cells synchronized in the early G1 phase by serum deprivation results in an immediate increase in the rate of $\mathrm{Zn}$ uptake by about 5 -fold. On the other hand, serum 
Grummt et al.
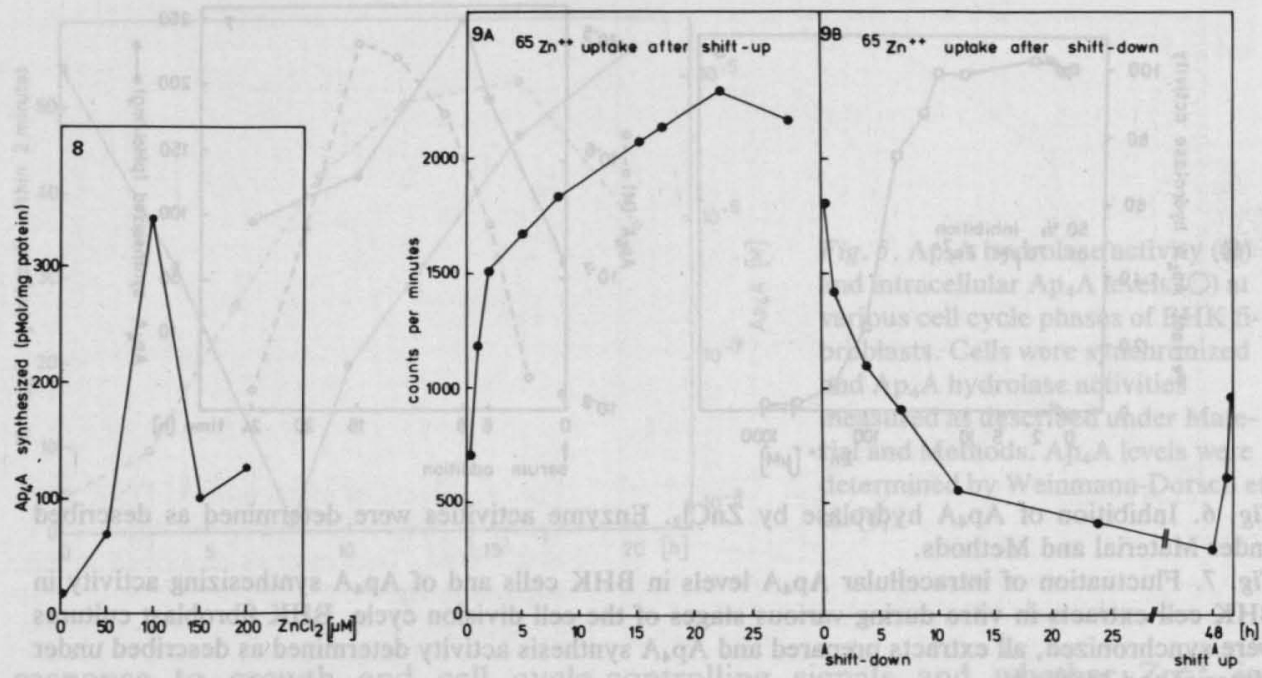

Fig. 8. $\mathrm{Zn}^{2+}$ dose dependency of $\mathrm{Ap}_{4} \mathrm{~A}$ synthesis activity in BHK fibroblast extracts. Cells were synchronized, extracts prepared $8 \mathrm{~h}$ after serum addition and assayed for $\mathrm{Ap}_{4} \mathrm{~A}$ synthesis at various $\mathrm{ZnCl}_{2}$ concentrations as described under Materials and Methods.

Fig. 9. Rate of $\mathrm{Zn}$ uptake in BHK fibroblasts under shift-up and shift-down conditions. $(A)$ BHK fibroblasts were arrested in early G1 phase by serum deprival as described under Materials and Methods, $10 \%$ serum was added at time zero and ${ }^{65} \mathrm{Zn}$ uptake measured by pulse labelling for $60 \mathrm{~min}$ as described in Methods. $(B)$ Serum was withdrawn from the medium of exponentially growing BHK cells at time zero and the medium replenished at $48 \mathrm{~h}$.

withdrawal causes a 5 -fold decrease of uptake rates for ${ }^{65} \mathrm{Zn}$ (fig. $9 \mathrm{~B}$ ). Thus, the intracellular zinc content could be controlled either by mitogenic stimulation or by growth arrest.

\section{DISCUSSION}

Taking together the data on $\mathrm{Ap}_{4} \mathrm{~A}$ that have been accumulated during the last 6-8 years it is very suggestive that $\mathrm{Ap}_{4} \mathrm{~A}$ acts as a chemical messenger or 'metabolic symbol' [19] of mitogenic induction similar to cAMP in hormone induction. The interaction between growth factors and their cognate receptors in cellular membranes could trigger signals which are transmitted into a central intracellular response, i.e. 1000 -fold expansion of the $\mathrm{Ap}_{4} \mathrm{~A}$ pool. Whether $\mathrm{Ap}_{4} \mathrm{~A}$ pools are regulated primarily on the level of biosynthesis, degradation or on a combination of both, is still a matter of speculation. $\mathrm{Ap}_{4} \mathrm{~A}$ may interact directly with the replicative machinery, presumably after binding to its highly specific binding site on DNA polymerase $\alpha$ ( $\mathrm{Ap}_{4} \mathrm{~A}$ acceptor protein), acting either as an allosteric effector of the polymerase or by being involved in the priming reaction. These reactions of $A_{4} \mathrm{p}_{4} \mathrm{~A}$ could then cause the eventual intracellular response of mitogenic induction, i.e., onset of DNA replication at the G1/S-phase boundary of the cell division cycle.

Increasing evidence suggests that $\mathrm{Zn}^{2+}$ plays an important role in the trans- 


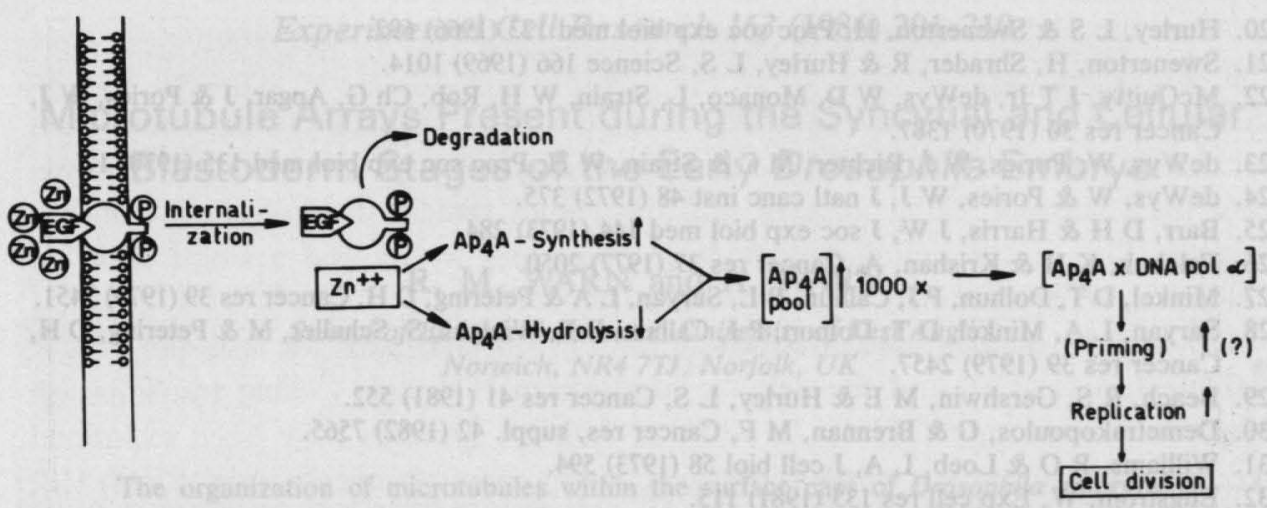

Fig. 10. Simplifying scheme of putative signal transmission upon mitogenic stimulation.

mission of the primary, extracellular mitogenic signal, i.e., growth factor-receptor binding, into intracellular events of mitogenic induction (see fig. 10). The observation that mitogenic induction leads to increased $\mathrm{Zn}^{2+}$ uptake and that $\mathrm{Zn}^{2+}$ is essential for the rising of intracellular $\mathrm{Ap}_{4} \mathrm{~A}$ concentrations and DNA replication suggests that $\mathrm{Zn}^{2+}$ is a 'second messenger' of mitogenic induction and that $\mathrm{Ap}_{4} \mathrm{~A}$ is a 'third messenger'. This assumption is supported by previously published observations indicating that zinc deficiency prevents cell and tumor growth [20-30] and/or inhibits DNA replication [31, 32].

This work was supported by the Deutsche Forschungsgemeinschaft (SFB 105).

\section{REFERENCES}

1. Graham, C F, Arms, K \& Gurdon, J B, Dev biol 14 (1966) 349.

2. Johnson, R T \& Harris, H, J cell sci 5 (1969) 625.

3. Rao, P N \& Johnson, R T, Nature 225 (1970) 159.

4. Rao, P N, Wilson, B A \& Sunkara, P S, Proc natl acad sci US 75 (1978) 5043.

5. Rapaport, E \& Zamecnik, P, Proc natl acad sci US 73 (1976) 3984.

6. Weinmann-Dorsch, Ch, Hedl, A, Grummt, I, Albert, W, Ferdinand, F-J, Friis, R R, Pierron, G, Moll, W \& Grummt, F, Eur j biochem 138 (1984) 179.

7. Weinmann-Dorsch, Ch, Pierron, G, Wick, R, Sauer, H \& Grummt, F, Exp cell res 155 (1984) 171.

8. Weinmann-Dorsch, Ch \& Grummt, F, Exp cell res 160 (1985) 47.

9. Grummt, F, Proc natl acad sci US 75 (1978) 371.

10. - Cold Spring Harbor symp quant biol 43 (1978) 649.

11. Grummt, F, Waltl, G, Jantzen, H M, Hamprecht, K, Huebscher, U \& Kuenzle, C C, Proc natl acad sci US 76 (1979) 6081.

12. Rapaport, E, Zamecnik, P C \& Baril, E F, Proc natl acad sci US 78 (1981) 838.

13. - J biol chem 256 (1981) 12148.

14. Zamecnik, P C, Rapaport, E \& Baril, E F, Proc natl acad sci US 79 (1982) 1791.

15. Grummt, F, Albert, W, Zastrow, G \& Schnabel, A, Proteins involved in DNA replication (ed U Hübscher \& S Spadari) p. 373. Plenum, New York (1984).

16. Grummt, F, Paul, D \& Grummt, I, Eur j biochem 76 (1977) 7.

17. Rubin, H, Proc natl acad sci US 69 (1972) 712.

18. Grummt, F, Plant mol biol 2 (1983) 41.

19. Tomkins, G, Science 189 (1975) 760. 


\section{Grummt et al.}

20. Hurley, L S \& Swenerton, H, Proc soc exp biol med 123 (1966) 692.

21. Swenerton, H, Shrader, R \& Hurley, L S, Science 166 (1969) 1014.

22. McQuitty, J T Jr, deWys, W D, Monaco, L, Strain, W H, Rob, Ch G, Apgar, J \& Pories, W J, Cancer res 30 (1970) 1387.

23. deWys, W, Pories, W J, Richter, M C \& Strain, W H, Proc soc exp biol med 135 (1970) 17.

24. deWys, W \& Pories, W J, J natl canc inst 48 (1972) 375.

25. Barr, D H \& Harris, J W, J soc exp biol med 144 (1973) 284.

26. Falchuk, K H \& Krishan, A, Cancer res 37 (1977) 2050.

27. Minkel, D T, Dolhun, P J, Calhun, B L, Saryan, L A \& Petering, D H, Cancer res 39 (1979) 2451.

28. Saryan, L A, Minkel, D T, Dolhun, P J, Calhun, B L, Wielgus, S, Schaller, M \& Petering, D H, Cancer res 39 (1979) 2457.

29. Beach, R S, Gershwin, M E \& Hurley, L S, Cancer res 41 (1981) 552.

30. Demetrakopoulos, G \& Brennan, M F, Cancer res, suppl. 42 (1982) 7565.

31. Williams, R O \& Loeb, L A, J cell biol 58 (1973) 594.

32. Engström, W, Exp cell res 135 (1981) 115.

Received June 6, 1985 